\title{
Manajemen Pendidikan Dan Pengajar Pada Sma Negeri Remboken Kabupaten Minahasa
}

\author{
Dr. Meike D. Mamentu, M.Si. \\ Fakultas Ekonomi Universitas Negeri Manado
}

\begin{abstract}
Abstrak: Kurikulum merupakan sesuaatu yang dicita-citakan dalam bidang pendidikan. Jadi apa yang direncanakan dalam kurikulum yang bersifat formal pada dasarnya mencerminkan cita-cita tentang wujud hasil pendidikan dan pengajaran yang ingin dicapai. Kurikulum diartikan sebagai pengalaman belajar diperoleh siswa dari sekolah dan kurikulum diartikan sebagai rencana belajar siswa (Hakim, 2008 : 5). Kurikulum adalah seperangkat rencana dan pengaturan mengenai tujuan, isi, dan bahan pelajharan serta cara yang digunakan sebagai pedoman penyelenggaraan kegiatan pembelajaran untuk tujuan pendidikan dan pengajaran yang hendak dicapai. Hal tersebut belum terealisasi sepenuhnya, kurikulum belum dikelolah secara optimal atau belum dikelolah secara efektif dan efisien sehingga perlu adanya bimbingan dan pelatihan.

Tujuan manajemen kurikulum bagi para guru dan kepala sekolah, agar dapat menyusun perangakat pembelajaran yang efektif dan efisien sesuai standar kompetnsi kelulusana para peserta didik. Metode yang digunakan adalah mengadakan pendidikan dan pelatihan penyusunan kurikulum bagi kepala sekolah dan para guru yang dibimbing oleh para pelatih yang profesional.

Pelaksnaan pendidikan dan pelatihan bagi para guru dan kepala sekolah di SMA Negeri Remboken meliputi kegiatan penyuluhan dan pelatihan manajemen kurikulum yang efektif dan efisien untuk semua mata pelajaran pada masing-masing program studi dan untuk setiap mata pelajaran yang diampuh oleh para guru sebagai realisasi kurikulum yang ditetapkan untuk dilaksanakan. Perangkat pembelajaran sebagai kurikulum baku disahkan oleh kepala sekolah, dimonitor dan dievaluasi untuk wujud pelaksanaanya berdasarkan standar ketuntasan minimal peserta didik dan standar kompetensi kelulusan serta untuk perbaikan pengembangan proses pembelajaran berkelanjutan.
\end{abstract}

Kata Kunci: Manajemen Pendidikan dan Pengajaran, Kurikulum Baku, perangkat pembelajaran guru

\section{Pendahuluan}

Analisis Situasi

Kurikulum merupakan sesuaatu yang dicita-citakan dalam bidang pendidikan. Jadi apa yang direncanakan dalam kurikulum yang bersifat formal pada dasarnya mencerminkan cita-cita tentang wujud hasil pendidikan dan pengajaran yang ingin dicapai. Dalam pelaksanaan kurikulum, para pelaksana harus dapat sebanyak mungkin mengenal berbagai perilaku yang muncul sebagai hasil kurikulum. Hal ini dimaksud agar bentuk-bentuk perilaku itu dapat dimunculkan secara terarah melalui suatu upaya yang disengaja, bahkan melalui pengembangan yang terencana.

Dalam pembinaan dan pengembangan kurikulum, proses pengkajian yaitu berhubungan dengan kurikulum diartikan sebagai perencanaan pembelajaran, kurikulum diartikan sebagai pengalaman belajar diperoleh siswa dari sekolah dan kurikulum diartikan sebagai rencana belajar siswa (Hakim, 2008:5).

Kurikulum tidak hanya sekedar mempelajari mata pelajaran, tetapi lebih mengembangkan pikiran, menambah wawasan serta mengembangkan pengetahuan yang dimilikinya. Kurikulum yang baik adalah sifatnya berkesinambungan. Menurut UU Sistem Pendidikan Nasional Nomor 20 Tahun 2003 menyatakan pengembangan kurikulum dilakukan dengan mengacu pada Standar Nasional Pendidikan untuk mewujudkan Tujuan Pendidikan Nasional. Kurikulum juga bertitik tolak dari masalah kehidpan yang disesuaikan dengan timgkat perkembangan dan minat serta kebutuhan individu, dan dikembangkan oleh guru secara bersama. Dalam Pasal 1 ayat (19) dijelaskan bahwa "Kurikulum adalah seperangkat rencana dan pengaturan mengenai tujuan, tujuan, isi, dan bahan pelajharan serta cara yang digunakan sebagai pedoman penyelkenggaraan kegiatan pembelajaran untuk mencapai tujuan pendidikan dan pengajaran tertentu.

Dari gambaran tentang kurikulum tersebut, memberi suatu penegasan bahwa kurikulum perlu dkelolah dengan baik.sesuai tujuan pendidikan dan pengajaran.

Permasalahan yang timbul dilapangan dalam hal ini disekolah sebagai pengelolah dan penyelenggara pendidikan dan pengajaran, kurikulum belum dikelolah secara optimal atau belum dikelolah secara efektif dan efisien. Hal ini dapat dilihat dari proses pembelajaran dikelas yang dilaksanakan oleh guru. Para guru dalam melaksanakan pembelajaran dikelas kurang variatif terutama dalam penggunaan 
metode pembelajran. Demikian juga dengan penggunaan media pembelajaran yang belum maksimal. Komponen-komponen kurikulum yang belum dimaksimalkan secara efektif dan efisien adalah komponen tujuan, dimana dalam penentuan tujuan belum menampakkan arah atau hasil yang diharapkan. Komponen isi atau materi pembelajaran masih kurang menitik beratkan pada pengalaman belajar. Komponen metode masih kurang variatif dengan strategi yang tepat. Komponen evaluasi dalam proses pembelajran belum mencerminkan proses belajar secara tepat dan proses evaluasi lebih melihat pada salah atau benar. Komponen kurikulum ini belum dapat dimaksimalkan oleh para guru dipihak sekolah.

Gambaran permasalahan diatas terjadi pada lembaga pendidikan disekolah yang melaksanakan pendidikan dan pengajaran seperti pada SMA Negeri Remboken. Manajemen kuriukulum di SMA Negeri Remboken sudah berjalan dengan baik, tapi belum maksimal, masih ada aspek-aspek kurikulum yang perlu diperhatikan terutama dalam pengembangannya. Pengembangan yang menyangkut pengelolaan ekstrakurikuler dan kokurikuler yang belum dikelolah secara integritas, pemanfaatan sumber daya kurikulum yang belum diberdayakan secara maksimal sehingga pengelolaannya belum efektif. Selain itu juga yang berhubungan dengan partisipasi masyarakat dalam membantu mengembangkan kurikulum yang belum maksimal.

\section{Identifikasi Dan Perumusan Masalah}

Pengembangan kurikulum dalam pengelolaan SMA Negeri Remboken perlu pelatihan bagi para guru dan kepala sekolah melelui pelaksanaan manajemen kurikulum yang efektif dan efisien dalam perencanaan perangkat pembelajaran dan pelaksanaannya. Tahapan dalam manajemen kurikulum sekolah :

1. Melaui tahap perencanaan

2. Tahap Pengorganisasian dan Koordinasi.

3. Tahap Pelaksanaan dan

4. Perlu adanya tahap evaluasi untuk pencapai kurikulum

\section{TARGET KEGIATAN}

Yang menjadi tujuan dan target kegiatan pelatihan manajemen kurikulum yang efektif dan efisien pada lembaga pendidikan yang mengelolah kurikulum pendidikan dan pengajaran di SMA Negeri Remboken dapat dirumuskan sebagai berikut :

1. Pengelolaan kurikulum mengikuti tahapan manajemen kurikulum yang efektif dan efisien

2. Kurikulum disusun dan dilasanakan sesuai standar baku yang berlaku

3. Para penyusun dan penyelenggara kurikulum yaitu guru dan kepala sekolah dapat memaksimalkan kurikulum sesuai tujuan pendidikan dan pengajaran disekolah yang berstandar nasional.

4. Rumusan kurikulum dapat dijabarkan seefektif dan seefisien mungkin yang menjadfi pedoman bagi kepala sekolah dan para guru dalam melaksanakan tugas pendidikan dan pengajaran

Dengan adanya kegiatan ini, maka diharapkan :

1. Para guru dan kepala sekolah dapat menyusun kurikulum secara tepat sesuai urutan penataan manjemen kurikulum yang efektif dan efisien

2. Para guru dan kepala sekolah dapat melaksanakan kurikulum sesuai standar pendidikan nasional pada setiap lembaga pendidikan

3. Para guru dan kepala sekolah dapat merumuskan kurikulum sesuai tujuan pendidikan dan pengajaran dari setiap satuan mata pelajaran yang menjadi tugas guru disekolah, dan menjadi pedoman dalam melaksanakan pendidikan dan pengajaran sebagai aturan baku

\section{Luaran Kegiatan}

Setelah diadakannya pelatihan manajemen kurikulum yang efektif dan efisien maka para guru dapat mengelolah perangkat pembelajaran sesuai dengan kurikulum baku yang disahkan kepala sekolah untuk dilaksanakan berupa :

1. Program pengajaran tahunan

2. Kalender pendidikan tahun pelajaran

3. Program pengajaran semester

4. Kriteria ketuntasan belajar minimal (KKM)

5. Silabus Permbelajaran

6. Rencana pelaksanaan pembelajara

7. Daftar Nilai dan Analisis Pencapaian Ketuntasan Belajar Siswa

8. Program Remedial

9. Pengayaan Siswa

10. Lembar Pengamatan Sikap 
11. Daftar hadir guru-guru dalam melaksanakan tugas sebagai kontrol kepala sekolah

\section{Metode dan sasaran kegiatan}

Dalam kegiatan ini digunakan metode pelaksanaan kegiatan berupa: Ceramah, Tanya Jawab dan pelatihan penyusunan kurikulum baku bagi kepala sekolah dan guru-guru untuk melaksanakan pembelajaran disekolah.Yang menjadi sasaran dari kegiatan pelatihan ini secara khusus adalah para guru yang diberi tugas kepala sekolah sebagai pengelolah kurikulum dan secara implesit menjabarkan kurikulum dalam perangkat pembelajaran sebagai pedoman melaksanakan tugas pendidikan dan perngajaran pada masing-masing mata pelajaran yang diajarkan, dan pembelajaran yang akan dilaksanakan sesuai kalendek kegiatan periode pembelajaran kerja akademik disekolah.

\section{Lokasi Kegiatan}

Pelaksanaan kegiatan penyuluhan dan pelatihan ini bertempat di sekolah SMA Negeri Remboken Kabupaten Minahasa

\section{Jadwal Kegiatan}

Kegiatan dilaksanakan pada bulan Maret sampai dengan Mei 2013 dan menurut jadwal kegiatan pengabdian pada masyarakat sebagai berikut:

\section{KALENDER KEGIATAN PENGABDIAN PADA MASYARAKAT:}

\begin{tabular}{|c|c|c|c|}
\hline NO. & JENIS KEGIATAN & $\begin{array}{l}\text { ALOKASI } \\
\text { WAKTU }\end{array}$ & PELAKSANA dan PESERTA PELATIHAN \\
\hline 1. & Penyajian Materi Kurikulum & Maret 2013 & $\begin{array}{l}\text { Dr. Meike D.Mamentu, M.Si.; Kepala Sekolah } \\
\text { dan para guru }\end{array}$ \\
\hline 2. & $\begin{array}{l}\text { Penyusunan lembar kerja kurikulum yang } \\
\text { dirumuskan dalam perangkat pembelajaran }\end{array}$ & Maret 2013 & $\begin{array}{l}\text { Dr.Meike.D.MamentuM.Si; guru-guru dan } \\
\text { Kepala sekolah }\end{array}$ \\
\hline 3. & $\begin{array}{l}\text { Perumusan kurikulum baku berkualifikasi } \\
\text { nasional yang dirumuskan dalam perangkat } \\
\text { pembelajaran sebagai pedoman guru }\end{array}$ & April 2013 & $\begin{array}{l}\text { Dr.Meike D.Mamentu M.Si. para guru, dan } \\
\text { kepala sekolah }\end{array}$ \\
\hline 4. & Perampungan laporan hasil pelatihan & April 2013 & $\begin{array}{l}\text { Dra. Meike D. Mamentu M.Si. para guru dan } \\
\text { kepala sekolah }\end{array}$ \\
\hline 5. & Pelaporan hasil pelatihan & Mei 2013 & $\begin{array}{l}\text { Dra. Meike D. Mamentu M.Si. para guru dan } \\
\text { kepala sekolah }\end{array}$ \\
\hline
\end{tabular}

\section{Bentuk dan Realisasi Kegiatan}

Bentuk dan realisasi kegiatan yang dilakukan adalah dengan mengadakan:

1. Pelatihan mengenai materi-materi kurikulum mengikuti tahapan manajemen kurikulum yang efektif dan efisien

2. Pelatihan bagi para guru dan kepala sekolah utuk menyusun kurikulum sesuai perangkat kurikulum berstandar nasional yang tersedia dan memenuhi standar baku untuk dilaksanakan, dirumuskan dalam bentuk perangkat pembelajaran

3. Pelatihan bagi para guru dan kepala sekolah untuk memiliki rumusan kurikulum baku dan dapat dilaksanakan sesuai satuan mata pelajaran yang diajarkan para guru pada masing-masing mata pelajaran yang memenuhi Standar Nasional pendidikan. Rumusan berbentuk perangkat pembelajaran guru yang menjadi pedoman

4. Penyuluhan Materi. Untuk materi penyuluhan dalam pelatihan para guru dibekali materi tentang prosedur dan penetapan kurikulum berbasis kompetensi yang berstandar nasiuonal yaitu, Konsep Manajemen, Konsep Kurikulum, Konsep manajemen kurikulum dan kurikulum berbasis kompetensi yang berkualifikasi standar nasional serta seperangkat pembelajaran sebagai tugas guru yang disahkan kepala sekolah untuk dilaksanakan dalam pendidikan dan pembelajaran. Pelaksanaan pendidikan dan pembelajran disahkan kepala sekolah, dimonitor pelaksanaanya dan dievaluasi untuk tingkat capaian pembelajaran serta untuk perbaikan pengembangan proses pembelajaran berkelanjutan.

Pelaksnaan pengabdian yang disekolah SMA Negeri Remboken meliputi kegiatan penyuluhan dan pelatihan manajemen kurikulum yang efektif dan efisien bagi kepala sekolah dan guru-guru mata pelajaran yang menyusun seperangkat pembelajaran berupa program pengajaran sebagai realisasi kurikulum yang ditetapkan. Pelatihan yang dilakukan berupa pemberian materi-materi kurikulum berupa tahapan manajemen kurikulum yang efektif dan efisien, konsep manajemen, konsep kurikulum, strategi kurikulum, pengorganisasia krikulum, komponen kurikulum dan pelaksanaan kurikulum berbasis kompetensi yang berkualifikasi standar nasional Penyusunan seperangkat pembelajaran sebagai realisasi kurikulum yang merupakan tugas guru dan disahkan kepala sekolah untuk dilaksanakan dalam pendidikan dan pengajaran disekolah. Pelaksanaan pendidikan dan pembelajran disahkan kepala sekolah, dimonitor pelaksanaanya dan dievaluasi untuk tingkat 
capaian pembelajaran masing-masing guru mata pelajaran dengan standar ketuntasan minimal peserta didik serta untuk perbaikan pengembangan proses pembelajaran berkelanjutan.

\section{SOLUSI DAN PENDEKATAN TERHADAP PERMASALAHAN}

Serangkaian hambatan yang dialami kepala sekolah dan para guru, ini menunjukkan bahwa kinerja kepala sekolah guru dalam melaksankan pendidikan dan pengajran berpengaruh secara langsung positif dan signifikan kepada keberhasilan peserta didik. Karakter kepala sekolah dan profesionalisasi guru-guru dapat diukur dengan keberhasilan dalam mengkaji kurikulum baku dan merumuskan seperangkat pembelajaran sebagi panduan melaksanakan tugas. Perangkat pembelajran dapat memuat materi ajar dari muatan kurikulum yang menjadi tujuan pembelajaran disekolah. Salah satu kompetensi yang harus dimiliki oleh kepala sekolah ialah kompetensi dalam mengelola dan mengembangkan kurikulum dan pembelajaran di sekolah dan dilaksanakan oleh para guru. Yang dimaksud dengan kurikulum dalam uraian ini adalah seperangkat rencana dan pengturan mengenai isi dan bahan pelajaran serta cara penggunaan proses pembelajaran sebagai pedoman penyelenggarakan belajar mengajar bagi para guru disekolah. Program mengajar di sekolah terdiri dari program umum dan program khusus. Program pengajaran umum diselenggarakan di setiap jenjang dan tingkat kelas. Untuk dapat mewujudkan kurikulum dan program-program pengajaran yang disebut di atas, maka kepala sekolah perlu memiliki pengetahuan dan keterampilan dalam mengelola kurikulum dan program-program pengajaran sesuai tujuan pembelajaran di sekolah yang ditugaskan kepada guru untuk melaksanakannya. Garisgaris materi dalam perangkat pembelajran memuat manajemen kurikulum pembelajran disekolah seefektif dan seefisien mungkin dan dirumuskan sebagai administrasi pembelajran yang menjadi pedoman guru.

\section{B. PELAKSANAAN PELATIHAN MANAJEMEN KURIKULUM BAGI KEPALA SEKOLAH DAN GURU-GURU \\ 1. Penyajian Materi \\ 1.1. Pengertian Manajemen}

Menurut Terry dan Rue (1992: 5), Manajemen adalah "suatu proses atau kerangka kerja, yang melibatkan bimbingan atau pengarahan suatu kelompok orang-orang ke arah tujuan-tujuan organisasional atau maksud-maksud yang nyata. Manajemen pada dasarnya memiliki 5 fungsi, yaitu : (1) Planning (Perencanaan): menentukan tujuan yang hendak dicapai, dan bagaimana cara mencapai tujuan tersebut. (2) Organizing (Pengorganisasian): mengelompokkan berbagai kegiatan dan memberikan kekuasaan untuk melaksanakan kegiatan tersebut. (3) Staffing (Kepegawaian): menentukan sumberdaya manusia/guru yang dibutuhkan, serta menyaring, melatih, dan mengembangkan tenaga kerja. (4) Motivating (Pemotivasian): mengerahkan perilaku manusia ke arah tujuan yang telah ditentukan. (5) Controlling(Pengawasan): menetapkan ukuran untuk pelaksanaan tujuan, memonitor, dan jika terjadi penyimpangan, harus ditemukan sebabnya dan memberi tindakan korektif bila diperlukan. Manajemen Pendidikan sendiri menurut Bush (2003) seperti yang dikutip oleh Amtu, adalah kegiatan yang bersangkutan dengan operasionalisasi organisasi pendidikan. Manajemen pendidikan harus fokus pada tujuan pendidikan. Di Indonesia sendiri, tujuan pendidikan nasional adalah mencerdaskan kehidupan bangsa dan mengembangkan manusia Indonesia seutuhnya, yaitu manusia yang beriman dan bertaqwa terhadap Tuhan Yang Maha Esa dan berbudi pekerti luhur, memiliki pengetahuan dan keterampilan, kesehatan jasmani dan rohani, kepribadian yang mantap dan mandiri serta rasa tanggung jawab kemasyarakatan dan kebangsaan (UU RI no 2 tahun 1989).

\subsection{Pengertian Kurikulum}

Pengertian kurikulum mengalami perkembangan dan terus mengalami perdebatan dari waktu ke waktu. Berbagai pendapat berbeda mengenai definisi kurikulum, misalnya disebutkan oleh Nasution adalah sebagai berikut dalam (1) Saylor dan Alexander (1956) menyebutkan bahwa kurikulum adalah segala usaha sekolah untuk mempengaruhi anak belajar, apakah dalam ruangan kelas, di halaman sekolah, atau di luar sekolah. (2) Albertycs (1965) memandang kurikulum sebagai semua aktifitas yang disediakan oleh sekolah untuk siswa.(3) Smith, Stanley, dan Shores memandang kurikulum sebagai sejumlah pengalaman potensial yang diatur di sekolah dalam rangkan mendisiplinkan anak dan pemuda agar mereka dapat berpikir dan berbuat sesuai masyarakatnya.(4) Edward A. Krug (1960) melihat kurikulum sebagai cara-cara dan usaha untuk mencapai tujuan persekolahan. Walaupun terdapat perbedaan definisi mengenai kurikulum ini, kita dapat menyimpulkan bahwa kurikulum ini merupakan suatu rencana pembelajaran untuk mencapai tujuan yang telah ditetapkan sebelumnya. Dalam rencana tersebut juga mencakup media dan strategi yang akan digunakan dalam pembelajaran. Menurut pandangan lama, kurikulum merupakan sejumlah mata pelajaran yang harus ditempuh murid untuk memperoleh ijazah. Pandangan ini memberi implikasi, bahwa semua murid harus mengikuti mata pelajaran yang sama. Selain itu, peran aktif dipegang oleh guru untuk menyampaikan materi pembelajaran. Pada perkembanngannya, definisi kurikulum meluas. Misalnya pengertian yang diberikan oleh Romine (1954) seperti yang dikutip oleh Hamalik (2008:17) "Curriculum is interpreted to mean all of the organized courses, 
activities, and experiences which pupils have under direction of the school, whether in the classroom or not".Kurikulum mencakup semua kegiatan dan pengalaman siswa, selama masih menjadi tanggung jawab sekolah. Selain itu, kegiatan pembelajaran dapat dilakukan di dalam atau di luar kelas, sehingga kegiatan ekstrakurikuler pun sebenarnya termasuk dalam kurikulum. Dalam pengertian yang lebih luas ini, menjadi kewajiban guru untuk mengajar dengan cara yang lebih bervariasi, sehingga siswa menjadi lebih aktif. Secara etimologi kurikulum berasal dari kata "curere"( Latin) yang berati berlari cepat. Dari kata "curre"(katakerja) menjadi "curricum" "(katabenda). Jadi secara etemilogi,kurikulum berarti tempat bagi siswa berlomba untuk mencapai suatu (tingkat pengetahuan-untuk dapat ijazah). Secara tradisional, kurikulum diartikan sebagai jumlah mata pelajar yang direncanakan di bawah tanggung jawab sekolah. Yang dimaksud dengan kurikulum adalah segala kegiatan belajar yang terhubung dengan program pendidikan di sekolah yang meliputi kegiatan intrakurikuler, kokurikuler,dan ekstrakuler. Yang dimaksud dengan kurikulum (seperti yang disusun dalam Pedoman Kurikulum) adalah seperangkat rencana dan pengetahuan mengenai isi dan bahan pelajaran serta proses belajar mengajar yang dikerjakan guru.

\section{1,3 Kegiatan Manajemen Kurikulum}

Setelah mengetahui pengertian manajemen dan kurikulum, dapat kita simpulkan bahwa manajemen kurikulum adalah suatu proses dan kerangka kerja yang untuk mencapai keberhasilan kurikulum. Kegiatan manajemen kurikulum dapat dikaitkan dengan dua hal, yaitu: yang berkaitan dengan tugas guru, dan yang berkaitan dengan proses pembelajaran.

(1) Kegiatan Yang Berkaitan dengan Tugas Guru

Pembagian tugas pembelajarkan. Pembagian tugas biasanya dilakukan dalam rapat guru pada awal tahun pelajaran atau menjelang awal semester baru. Pembagian tugas membina kegiatan ekstrakurikuler. Kegiatan ektrakurikuler atau kegiatan tambahan diluar kurikulum yang berlaku ini seperti kegiatan pramuka, koperasi, unit kesehatan sekolah, olahraga, kesenian, dan lain-lain.

(2) Kegiatan yang Berkaitan dengan Proses Pelaksanaan Pembelajaran

Penyusunan jadwal pelajaran. Jadwal pelajaran merupakan penjabaran dari seluruh program pembelajaran di sekolah. Jadwal pelajaran merupakan pedoman bagi guru bahwa dia akan melaksanakan pembelajarkan di kelas mana dan hari apa saja, serta jam berapa saja.

Penyusunan program pembelajaran. Kegiatan penyusunan program pembelajaran ini meliputi: (a) Menghitung jumlah pokok bahasan yang harus disampaikan dalam jangka waktu tertentu (semester atau catur wulan); (b) Menghitung jumlah jam pelajaran yang tersedia menurut kurikulum yang berlaku; (c) Menghitung jumlah jam efektif pada semester atau catur wulan berdasarkan kalender akademik yang berlaku; (d) Membuat Rencana Pelaksanaan Pembelajaran untuk jangka waktu tertentu (satu semester atau catur wulan).

Pengisian daftar kemajuan kelas. Menggambarkan tentang kemajuan kelas tentang penguasaan materi pelajaran.

Kegiatan mengelola kelas. Merupakan upaya yang dilakukan guru dalam melaksanakan proses pembelajaran agar tujuan pembelajaran bias tercapai secara efektif dan efisien. Hal ini menyangkut strategi pembelajaran, pemanfaatan media, tempat duduk, dan lain-lain.

Penyelenggaraan evaluasi hasil belajar. Evaluasi hasil belajar berguna untuk mendapatkan umpan balik bagi guru tentang ketercapaian tujuan pembelajaran.

Laporan hasil belajar. Hasil belajar yang diperoleh oleh siswa harus dilaporkan kepada orang tua atau wali murid ini disebut rapor.

Kegiatan bimbingan dan penyuluhan. Kegiatan bimbingan dan penyuluhan ditujukan bagi seluruh peserta didikdi sekolah tanpa terkecuali. Bimbingan penyuluhan tidak hanya untuk siswa yang bermasalah saja tapi semua siswa, termasuk siswa yang berprestasi.

\subsection{Pengorganisasian Kurikulum}

Menurut Sutikno, terdapat empat bentuk pengorganisasian kurikulum yang bisa diterapkan dalam lembaga pendidikan.

(1) Separated Subject Curriculum. Kurikulum ini menyajikan segala bahan pelajaran dalam berbagai macam mata pelajaran (subject) yang terpisah-pisah satu sama lain, seakan-akan ada batas pemisah antara mata pelajaran yang satu dengan yang lain, juga antara satu kelas dengan yang lain.

(2) Correlated Curriculum. Bentuk ini menghendaki agar mata pelajaran satu sama lain ada hubungan, bersangkut paut (correlated) walaupun mungkin batas-batas yang satu dengan yang lain masih dipertahankan. Korelasi dapat dilakukan dengan berbagai macam cara, yaitu: (a) Antara dua mata pelajaran diadakan hubungan secara incidental; (b) Terdapat hubungan yang lebih erat, apabila suatu pokok bahasan tertentu dibahas dalam berbagai mata pelajaran; (c) Mempersatukan beberapa mata pelajaran dengan menghilangkan batas masing-masing. 
(3) Integrated Curriculum. Integrated Curriculum meniadakan batas-batas antara berbagai mata pelajaran dan menyajikan bahan pelajaran dalam bentuk unit atau keseluruhan. Dengan kebulatan mata pelajaran, anak diharapkan dapat dibentuk menjadi pribadi yang integrated yakni manusia yang selaras dengan lingkungan hidupnya.

(4) Core Curriculum. Pada prinsipnya core curriculum memberikan pelajaran yang umum. Dalam core curriculum diajarkan hal-hal yang perlu diketahui oleh setiap orang terlepas dari pekerjaan yang akan dilakukan kelak dalam masyarakat.

\section{Komponen Kurikulum}

Telah dibahas pada bagian pengertian kurikulum, bahwa kurikulum merupakan rencana demi mencapai tujuan pembelajaran yang telah ditetapkan. Untuk mencapai tujuan tersebut, kurikulum harus direncanakan sebaik-baiknya. Dalam kurikulum itu sendiri terdapat 4 (empat) komponen, yaitu: komponen tujuan, komponen isi, komponen metode, dan komponen evaluasi.

(1)

Komponen Tujuan Kurikulum

Kurikulum merupakan suatu program yang dimaksudkan untuk mencapai tujuan pendidikan. Tujuan itulah yang dijadikan arah atau acuan segala kegiatan pendidikan yang dijalankan. Berhasil atau tidaknya program pengajaran di sekolah dapat diukur dari seberapa jauh dan banyaknya pencapaian tujuan-tujuan tersebut. Tujuan kurikulum harus dijabarkan dari tujuan umum pendidikan nasional, kemudian dikhususkan kembali menjadi tujuan-tujuan yang lebih detail dan lebih sempit lingkupnya. Tujuan-tujuan tersebut meliputi tujuan Institusional, Tujuan Kurikuler, dan Tujuan Instruksional. Tujuan Pendidikan Nasional. Menurut UU RI no 20 tahun 2003 tentang Sisdiknas, disebutkan bahwa Pendidikan nasional berfungsi mengembangkan kemampuan dan membentuk watak serta peradaban bangsa yang bermartabat dalam rangka mencerdaskan kehidupan bangsa, bertujuan untuk berkembangnya potensi peserta didik agar menjadi manusia yang beriman dan bertakwa kepada Tuhan Yang Maha Esa, berakhlak mulia, sehat, berilmu, cakap, kreatif, mandiri, dan menjadi warga negara yang demokratis serta bertanggung jawab. Tujuan Institusional adalah tujuan yang harus dicapai oleh suatu lembaga pendidikan, artinya apa yang seharusnya dimiliki oleh siswa setelah tamat dari lembaga pendidikan tersebut. Oleh karena itu tujuan institusional merupakan kemampuan yang diharapkan untuk dimiliki siswa setelah mereka menyelesaikan program studinya pada lembaga tersebut.

Dalam Permendiknas No. 22 Tahun 2007 dikemukakan bahwa tujuan pendidikan tingkat satuan pendidikan dasar dan menengah dirumuskan mengacu kepada tujuan umum pendidikan nasional. berikut. Tujuan pendidikan menengah adalah meningkatkan kecerdasan, pengetahuan, kepribadian, akhlak mulia, serta keterampilan untuk hidup mandiri dan mengikuti pendidikan lebih lanjut.

Tujuan Kurikuler adalah tujuan bidang studi atau mata pelajaran. Bila dilihat secara operasional, maka tujuan kurikuler adalah rumusan kemampuan yang diharapkan dapat dimiliki anak didik setelah menyelesaikan atau mempelajari suatu bidang studi atau mata pelajaran tersebut. Tujuan kurikuler pada Kurikulum Tingkat Satuan Pendidikan tergambarkan pada standar isi dan standar kompetensi lulusan tiap mata pelajaran yang harus dikuasai oleh siswa.Tujuan Instruksional

Tujuan Instruksional adalah tujuan pengajaran atau tujuan yang diharapkan dapat dicapai pada saat terjadinya proses belajar mengajar atau setelah proses pembelajaran. Tujuan ini tergambarkan pada tujuan pembelajaran yang dibuat guru untuk pada tiap kali pokok bahasan. Tujuan instruksional ini memuat berbagai hal yang harus dimiliki ataupun diuasai oleh siswa setelah satu pokok bahasan (atau dalam KTSP, satu Kompetensi Dasar) selesai dipelajari. guru mencantumkan tujuan ini pada Rencana Program Pengajaran yang dibuatnya.

(2) Komponen Isi / Materi Kurikulum

Komponen isi atau materi ini merupakan komponen kurikulum yang amat penting. Pada dasarnya komponen ini menjawab pertanyaan: "Apa yang akan dipelajari?" Isi dari kurikulum adalah materi atau bahan pelajaran dan pengetahuan atau pengalaman belajar yang harus diberikan kepada peserta didik untuk mencapai tujuan pendidikan. Untuk menentukan isi kurikulum tersebut harus disesuaikan dengan tingkat dan jenjang pendidikan, perkembangan yang terjadi dalam masyarakat, perkembangan ilmu pengetahuan dan teknologi, serta kondisi anak didik (psikologis anak) pada setiap jenjang pendidikan tersebut. Kriteria yang dapat digunakan untuk menetapkan isi, yakni: signifikansi, kebutuhan sosial, kegunaan, minat, perkembangan manusia, dan struktur disiplin ilmu. Atas dasar pemikiran diatas, perlu adanya seleksi bahan kurikulum, yaitu : (a). Bahan kurikulum harus sesuai, tepat, dan bermakna bagi perkembangan siswa. (b) Bahan kurikulum harus mencerminkan kehidupan sosio-kultural.(3) Bahan kurikulum harus dapat mencapai tujuan yang didalamnya mengandung aspek intelektual, emosional, sosial, dan moral keagamaan. 


\subsection{Komponen Strategi Pelaksanaan Kurikulum}

Strategi adalah pola-pola umum kegiatan guru dan murid dalam perwujudan kegiatan belajar mengajar atau kegiatan kurikuler untuk mencapai tujuan yang telah digariskan.Dalam strategi pelaksanaan suatu kurikulum akan tergambar bagi kita tentang cara-cara pelaksanaan dari komponen-komponen kegiatan proses belajar mengajar yang meliputi : penilaian, cara melaksanakan bimbingan dan penyuluhan, serta cara mengatur kegiatan sekolah secara keseluruhan.

Strategi pelaksanaan kurikulum memberi petunjuk bagaimana kurikulum tersebut dilaksanakan disekolah. Oleh karena itu, komponen strategi pelaksanaan kurikulum memegang peranan penting dalam percapaian tujuan pendidikan. Dan dalam pelaksanaannya, ada beberapa aspek yang perlu dipertimbangkan dalam melaksanakan kurikulum, antara lain :

(1) Tingkat dan jenjang pendidikan; dengan adanya jenjang/tingkat pendidikan tersebut berarti pula terdapat perbedaan dalam hal tujuan instutional, perbedaan isi dan struktur pendidikan, perbedaan strategi pelaksanaan kurikulum, perbedaan sarana kurikulum, sistem evaluasi, dan sebagainya.

(2) Proses belajar mengajar; proses belajar mengajar adalah kegiatan guru sebagai penyampai pesan/materi pelajaran dan siswa sebagai penerima pelajaran. Dalam proses belajar mengajar keduanya dituntut aktif sehingga terjadi interaksi dan komunikasi yang harmonis demi tercapainya tujuan pembelajaran. Tujuan pembelajaran adalah wujud/bentuk kurikulum yang telah ditetapkan/ direncanakan dalam bentuk program pengajaran.

\subsection{Komponen Evaluasi Kurikulum}

Evaluasi kurikulum merupakan penilaian terhadap suatu kurikulum sebagai program pendidikan untuk menentukan efesiensi, efektivitas, relevansi, dan produktivitas program dalam mencapai tujuan pendidikan. Kegiatan evaluasi ditujukan untuk menilai sejauh mana tujuan pendidikan dan pengajaran tercapai dan sejauh mana proses kurikulum itu berjalan seperti yang diharapkan. Hasil dari kegiatan evaluasi ini dapat dijadikan sebagai umpan balik (feed back) untuk mengadakan perbaikan dan penyempurnaan kurikulum selanjutnya. Evaluasi kurikulum dapat ditetapkan untuk mencapai dua sasaran, yakni evaluasi terhadap proses kurikulum dan evaluasi terhadap produk (hasil) kurikulum. Evaluasi terhadap proses kurikulum, dimaksudkan untuk mengetahui apakah proses itu berjalan secara optimal sehingga dapat memungkinkan tercapainya tujuan. Sedangkan evaluasi terhadap produk, dimaksudkan untuk menilai sejauh mana keberhasilan kurikulum dapat mengantarkan siswa kearah tujuan yang ditetapkan.

Menurut Kunandar, pengembangan kurikulum dijenjang sekolah dasar sampai sekolah menengah yang dikemangkan oleh sekolah dan komite sekolah berpedoman pada standar kompetensi lulusan standar isi, serta panduan penyusunan kurikulum yang dibuat BSNP, harus didasarkan perinsip-perinsip sebagai berikut. Kurikulum dilaksanakan berdasarkan komponen-komponen kurikulum yang ada.

\section{PELAKSANAAN KURIKULUM DALAM IMPLEMENTASI}

Tugas kepala sekolah ialah mengelola kurikulum dan kegiatan belajar-mengajar untuk tiap mata pelajaran dan dijabarkan oleh guru yang ditugaskan. Sebelum membahas pengelolaan kurikulum, perlu dicatat beberapa informasi penting sehubungan dengan pelaksanaan kurikulum. Kurikulum yang disusun secara baku dan berstandar mutu yang diharapkan dikaji bersama guru-guru untuk menyusun program pendidikan dan penyajaran yang meliput: (1) Waktu belajar dan penilaian. Kurikulum di Indonesia menerapkan sistem semester yang membagi waktu belajar satu tahun ajaran menjadi 2 bagian, yang masing - masing disebut semester. Jumlah hari belajar efektif satu tahun 240-245 hari, termasuk di dalamnya waktu bagi penyelenggaraan penilaian kemajuan hasil belajar siswa. Waktu mengajar 45 menit perjam di SMA dan sistem guru kelass mata pelajaran. Perencanaan kegiatan belajar- mengajar untuk guru meliputi, perencanaan tahunan, perencanaan semester, perencanaan tiap hari dalam bentuk persiapan. Tiap mata pelajaran perlu memanfaatkan berbagai sumber belajar. Perbaikan untuk mencapai tingkat penguasaan pengayaan untuk perluasan dan pendalaman bahan kajian tiap mata pelajaran yang direncanakan dan dilaksanaka. Penilaian perlu dikuasai kepala sekolah dan guru-guru. Dalam mengatur pelaksanaan penilaian adalah, ulangan harian (minimal 2 kali ), tugas-tugas yang diberikan, ulangan umum (semester 1 dan 2). Perhitungan penilaian untuk merngadakan penilaian hasil belajar dapat dirumuskan sebagai penilaian rapor. Penilaian dilakukan dengan cara kualitatif (amat baik,baik,dan sedang). Kenaikan kelas dipertimbangkan berdasarkan nilai semester ke-2. Kreterial untuk kelas I, dan II, kelas II ke kelas III perprogram menggunakan pedoman penilaian yang telah disusun. (2) Proses belajar mengajar, mencakup, menjabarkan kalender pendidikan, menyusun jadwal pelajaran dan pembagian tugas guru-guru, mengatur pelaksanaan peyusunan program pengajaran tahunan dan semester, persiapan dan penentuan materi mengajar, mengatur pelaksanaan, penyusunan program intrakurikuler dan eksrakulikuler secara keseluruhan dan mengatur pelaksanaan penilaian, mengatur pelaksanaan kenaikan kelas, membuat laboran kemajuan belajar siswa., mengartur usaha perbaikan dan pengayaan pengajaran. (3) Jabaran tugas guru (job description) dan beban mengajar ( teaching loads) Menyusun Program tahunan, semester, dan program persiapan mengajar guru 
dalam mendidik dan mengajar. (4) Sumber informasi adalah; kalender pendidikan, susunan program kulikulum, khusus alokasi waktu mata pelajaran yang bersangkutan, pokok bahasa yang tercantum dalam silabus tiap mata pelajaran dan hasil analisis yang mencakup luasnya serta tingkat kesulitan bahan pembelajaran (5) Model persiapan tahunan dan semester sesuai pertunjuk pelaksanaan proses belajar mengajar yaitu program tahunan, semester dan rencana pelaksanaan pembelajaran setiap tatap muka untuk setiap mata pelajaran. (6) Guru harus melaksanakan supervisi, proses belajar-mengajar dan supervisi administrasi penilaian untuk ketuntasan belajar siswa.. Kepala sekolah harus mempunyai kemampuan manajemen yang efektif dan kemampuan berkerja bersama para guru melalui aktifitas kerja guru sehingga memcapai ketuntasan belajar siswa serta mengevaluasi hasil kerja guru.

\section{HASIL RUMUSAN KURIKULUM, SEPERANGKAT PEMBELAJARAN GURU PEDOMAN PELAKSANAAN PEMBELAJARAN}

Hasil Kegiatan Perampungan kurikulum dalam rumusan seperangkat program pengajaran yang menajadi pedoman ruru melalui program pelatihan. Langkah awal yang akan dilakukan dalam proses pelaksanaan kegiatan adalah sosialisas pelaksanaan kegiatan. Kegiatan sosialisasi merupakan salah satu tahapan penting dalam menyampaikan hal-hal yang berkaitan dengan program dan kegiatan pengabdian. Kegiatan sosialisasi lebih ditekankan kepada pemberian pemahaman dan pengertian kepada para guru dan kepala sekolah berkaitan dengan penyusunan dan pelasanaan kurikulum yang efektif dan efisien. Kegiatan tersebut menyangkut transformasi gambaran ilmu pengetahuan dan teknologi dalam upaya memecahkan masalah yang dihadapi oleh kepala sekolah dan guru disekolah. Dalam kegiatan sosialisasi ini akan dijelaskan pula tentang teknologi yang akan digunakan untuk menunjang proses pembelajaran disekolah untuk mencapai tujuan pendidikan dan pengajaran yang bermutu.

Metode sosialisasi disini tidak hanya memberikan informasi secara tunggal tetapi dilakukan melalui berbagai pendekatan terutama melalui pendekatan etika dan budaya dalam melaksanakan tugas pengajaran disekolah. Hal yang sering terabaikan dalam setiap implementasi program adalah bagaimana memberi pemahaman tentang rasa memiliki kegiatan tersebut. Rasa memiliki dapat ditanamkan antara lain melalui pendekatan partisipatif, dimana para guru dan kepala sekolah dapat memberi diri untuk berpartisipasi secara aktif melalui kegiatan pelatihan pengkajian kurikulum dan program pengajaran berinteraksi bersama secara aktif dalam proses implementasi kegiatan. Hal tersebut sangat diperlukan mengingat faktor tersebut memberi andil besar terhadap kegagalan dan keberhasilan dalam penyusunan program pengajaran secara baku. Metode ini memungkinkan para guru kepala sekolah dapat berdiskusi, saling berbagi informasi, menambah dan menganalisis permasalahan atas program pengajaran yang disusun sesuai dengan kurikulum dan dapat diimplementasikan secara baik.

Setelah diadakan pelatihan penyusunan kurikulum dan penjabaran kurikulum dalam program pengajajaran pada guru-guru maka, masing-masimg guru telah memiliki seperangkat program pengajaran yang ditugaskan dan disahkan kepala sekolah untuk dilaksanakan oleh guru mata pelajaran dalam peroses belajar mengajar dikelas. Adapun komponen perangkat pembelajaran tersebut terdiri dari :

1. Program Pengajaran Tahunan

2. Kalender Pendidikan

3. Program Pengajaran Semester

4. $\quad$ Kriteria Ketuntasan Minimal (KKM)

5. Silabus Pembelajaran

6. Rencana Pelaksanaan Pembelajaran

7. Daftar Nilai Dan Pencapaian Ketuntasan Belajar Siswa

8. Program Remedial dan Analisis Siswa yang Mendapat Program Belajar Remedial

9. Analisis Penilaian Dan Analisis Pencapaian Ketuntasan Belajar Siswa

10. Lembar Pengamatan Sikap

11. Daftar hadir dan daftar nilai ketuntasan belajar

Sebagai pengesahan prorgam pengajaran dan pelaksanaannya selalu disahkan kepala sekolah dan dimonitor pelaksanaannya dengan mengambil daftar hadir kegiatan.

\section{Kesimpulan}

1. Pelaksnaan pendidikan dan pelatihan di SMA Negeri Remboken meliputi kegiatan penyuluhan dan pelatihan manajemen kurikulum yang efektif dan efisien bagi kepala sekolah dan guru-guru mata pelajaran yang menghasilkan seperangkat pembelajaran berupa program pengajaran yang baku sebagai realisasi kurikulum, berstandar ketuntasan minimal, berstandasr kompetensi kelulusan, dan berbasis kompetensi berkualifikasi standar nasional, yang ditetapkan untuk dilaksanakan.

2. Perangkat pembelajaran berupa kurikulum baku merupakan tugas guru yang disahkan kepala sekolah untuk dilaksanakan dalam pendidikan dan pengajaran disekolah. 
3. Pelaksanaan pendidikan dan pembelajran dilaksanakan guru berpedoman pada kurikulum yang ditetapkan. Dimonitor dan dievaluasi pelaksanaanya oleh kepala sekolah untuk setiap tingkatan capaian masingmasing mata pelajaran dengan standar ketuntasan minimal peserta didik serta untuk perbaikan pengembangan proses pembelajaran berkelanjutan.

\section{Saran}

Perangkat pembelajaran bagi para guru berupa kurikulum sebaiknya mengacu pada kurikulum 2013, bertaraf nasional dan internasional atau mengacu pada KKNI PERPRES No. 8 TAHUN 2012

\section{Kepustakaan}

[1]. Hernawan, Asep Hery, dkk, Pengembangan Kurikulum dan Pembelajaran, Jakarta : Universitas Terbuka, 2003.

[2]. ] Mohammad Ansyar, Dasar-dasar Pengembangan Kurikulum, (Jakarta: Depdikbud, 1989), hlm. 118-120

[3]. Indrakusuma, Amir Daien, Pengantar Ilmu Pendidikan, Surabaya : Usaha Nasional, 1993.

[4]. Khiron, Ahmad, Komponen Kurikulum dan Prosedur Pengembangan Kurikulum, http: // Koir.Multiply.Com, tanggal 19 April 2009.

[5]. Mansyur, Strategi Belajar Mengajar, Jakarta : Dirjen Binbaga Islam Depag RI, 1995.

[6]. Nasution, S. 1995. Asas-Asas Kurikulum. Jakarta: Bumi Aksara.

[7]. Nazhary, Pengorganisasian, Pembinaan dan Pengembangan Kurikulum, Jakarta : Deramaga, 1993.

[8]. Nurdin, Syafruddin, Guru Profesional dan Implementasi, Ciputat : Ciputat Press, 2005.

[9]. Soetopo, Hidayat dan Wasty Soemanto, Pembinaan dan Pengembangan Kurikulum, sebagai Substansi Problem Administrasi Pendidikan, Jakarta : Bumi Aksara, 1993.

[10]. Syarief, A.Hamid, Pengembangan Kurikulum, Surabaya : Bina Ilmu, 1996.

[11]. UU RI no 20 tahun 2003 tentang Sistem Pendidikan Nasional. 